\title{
小規模高齢者通所施設の利用実態と空間の使われ方の特性について ACTIVITIES AND CHARACTERISTICS OF SPACE USE IN MINI DAY CARE CENTERS
}

\author{
西野達也*, 長澤 泰** \\ Tatsuya NISHINO and Yasushi NAGASAWA
}

\begin{abstract}
In Japan, the space of day care centers run by the public insurance for the care needed is normaly unified into large one room type. The purpose of this study is to report the actual conditions of mini day care centers, to examine chracteristics of space use and also to discuss the possibility and limitation of mini day care centers. Interviews to staff and city government officers and on-site observations of activities were conducted in four mini day' care'centers in a city, Tokyo.Analysis of users attributions showed there were two types,'Health promoting Center'and 'House for the elderly with dementia.'And the former was also divided into two by whether they held activity programs or not,one was 'Salon type ' and another was 'Activity Program type.'And analysis of space use pattern, conbinations of numbers of activities and that of groups in a space, showed there was a condition peculiar to 'Salon type', that everybody shared a room with individual activities. It was named a 'pararell situation'. The paper concluded a possibility of mini day care center was to have such a social situation differnt from general day care centers, but also mentioned the limitation from the point of impossibility of continuous use of centers after they needed physical helps.
\end{abstract}

Keywords; mini day care centers, center types, whole condition in a space,pararell situation ミニデイサービスセンター、施設型、全体状況、パラレルな場

\section{1. 研究の背景と目的}

近年、日本の高齢者福祉政策は、高齢者の在宅生活の支援を重視 する方針へ移行しつつある。そのような中で、デイサービスセン ター（以後、一般型デイと略す）は、介護する家族の負担の軽減の ため、或いは高齢者本人の孤立感の解消の場として、自宅以外の場 所であることの意義がますます大きくなると考えられる。しかしな がら、現状では、いまだに利用者の視点に立つた施設づくりが行わ れているとは言い難い。例えば、システムの問題として、高齢者が 要介護状態になってから利用し始めてもなかなか馴染みにくい点、 或いは利用者の好みにかかわらず参加を求める集団的活動もある 点、利用日が指定される点等が挙げられる。そのような状況の中 で、介護保険制度の限界を超えるための自治体独自の試みも見られ る。その一つに東京都M市による補助金助成を受けたミニデイサービ ス施設（以後、一般的なミニデイサービスを「ミニデイ」と略し、 特にM市のミニデイを「ミニデイT.H.」と略す）がある。このミニ デイT.H.はいくつかの試行点を持つ。例えば、システム面において は要介護度認定とは異なる利用者設定や地域ぐるみの運営体制を取 る施設もある点、ハード面では、10人程度の小規模な施設である点 や既存の民家等を転用して施設として利用している点等である。本 稿の目的は、このミニデイT.H.を実験的な通所施設と位置づけ、ま
ずその利用実態を報告し、次にミニデイT.H.の空間の使われ方の特 性を考察し、さらにそれらをもとにミニデイの可能性と限界を論じ ることである。

\section{2. 本稿の位置づけ}

1979年に厚生省によってデイサービス事業が制度化されて以降、 一般型デイに関する建築計画の研究には多くの先行研究がある。そ れらの論点は、主に、利用者属性の把握、施設種分類による機能の 設定、施設内における利用者の行動の把握による空間計画的示唆、 施設配置論等である。例えば大原は、デの機能として虚弱老人等 に日常的生活上の援助と場所を提供し、また独居老人に社会的接触 の機会を与えることを指摘している非”。しかしながら、それ以降、 既に15年以上の歳月を経ており、当時、導入期であった一般型デイ も現在では成熟期にあり、また 2000 年の介護保険制度の導入もあっ て、通所施設をとりまく社会的な状況も大きく変化している。その ような状況において、本稿の調查対象のミニデイT.H.は、自治体の 補助金事業であるため、介護保険制度の枠からはずれた高齢者の ニーズが見られるものと思われる。その利用実態を明らかにするこ とは、そもそも通所施設全体の枠組みを再考する上でも重要と考える。
* 東京大学大学院工学系研究科 大学院生 $\cdot$ 修士 (工学) ** 東京大学大学院工学系研究科 教授. 工博
Graduate Student, Graduate School of Eng., The University of Tokyo, M. Eng. Prof., Graduate School of Eng., The University of Tokyo, Dr. Eng. 


\section{3. 研究の方法}

\section{3-1.本稿の構成}

本稿の具体的課題と内容は以下の通りである。

1）ミニデイT.H.の施設型を分類すること（第 4 章）

まず調查対象としたミニデイT.H.の事業主旨・概要を報告し、次 に各施設の利用者属性、利用人数規模、利用圈域、提供サービス、 プログラム等からミニデイT.H.をいくつかの施設型に分類する。 2）ミニデイT.H.の空間の使われ方の特性を明らかにすること（第5章）
次に各施設の空間の使われ方の特性を明らかにする。換言すれ ば、ミニデイT.H.の物理的環境の特性、即ち小規模であることその ものの検証が本章の課題である。そのために各施設の利用者スペー ス内の全体的状況を分析対象とした。既往研究では、個々の利用者 に着目し家具等の部分的な環境要素との関連を分析する手法によっ て、空間的あり方が追求されてきた部2)。しかし、本稿では、そもそ もテイは利用者にとって社会的接触の場であるとの認識に基づき、 利用者の空間内での行動を、単に部分的な空間要素との関係から捉

表・1.各施設の概要註3)

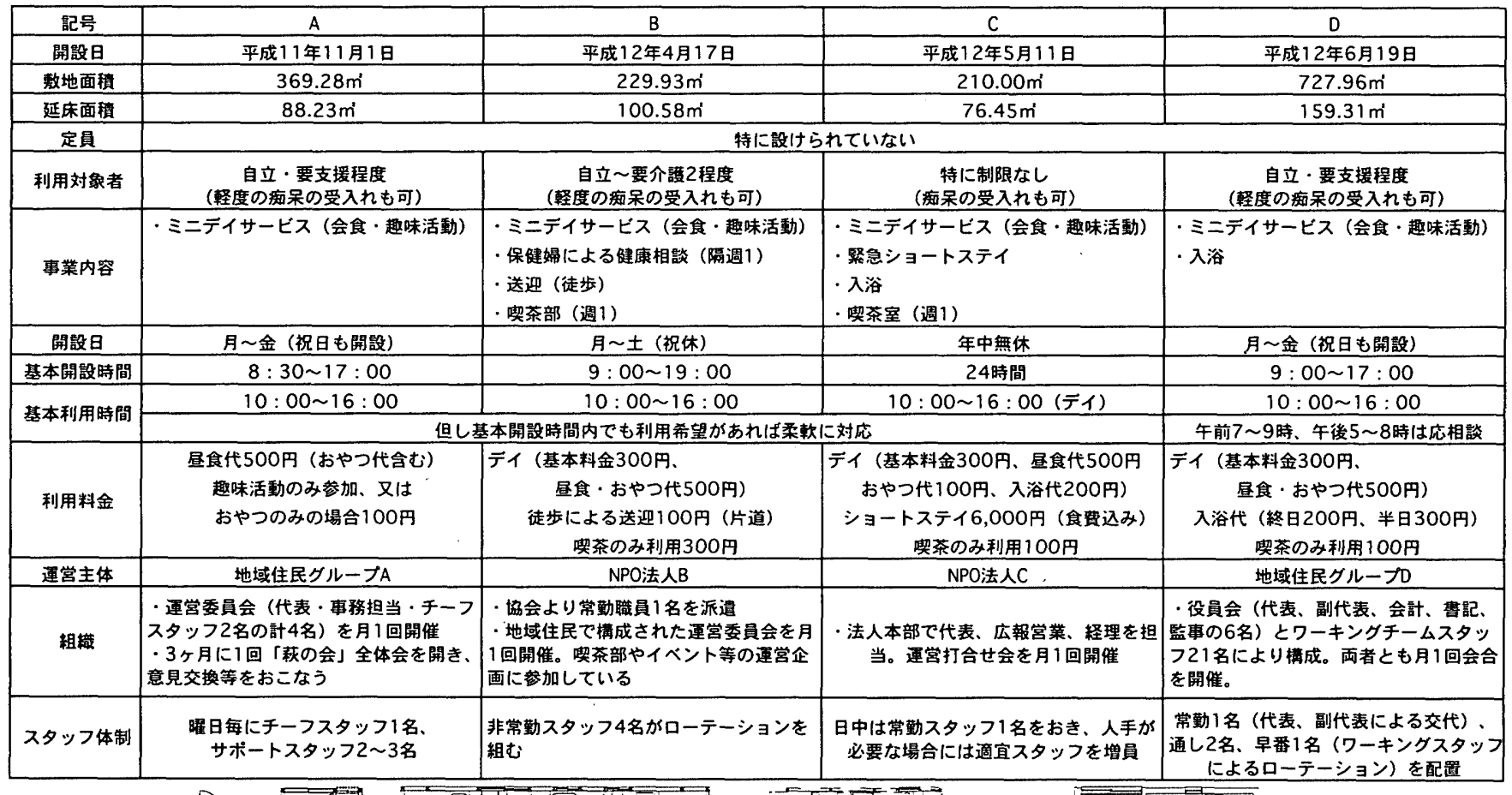

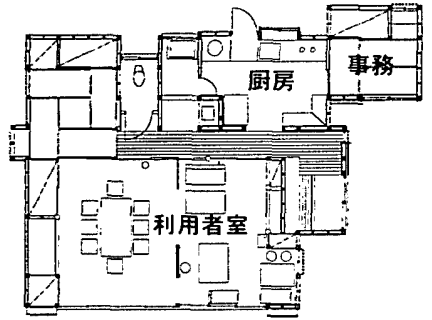

施設A

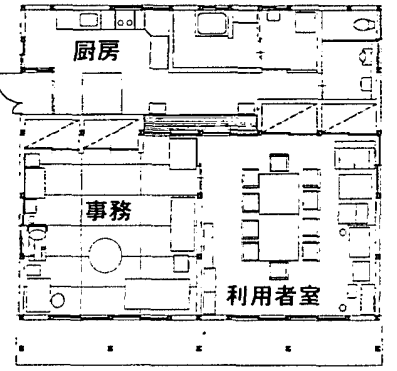

施設B

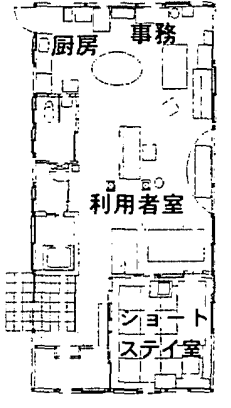

施設 C

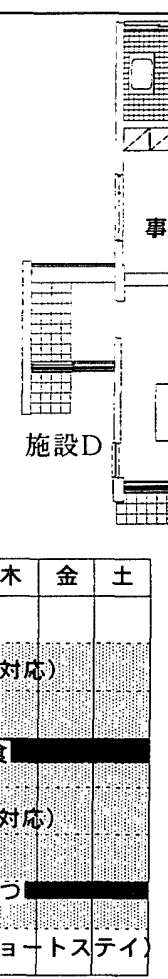

图・2.各施設の平面図(1:300)

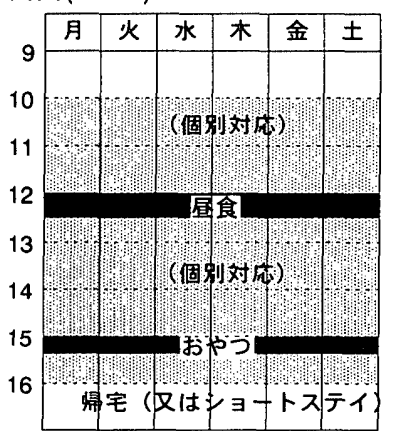

施設C

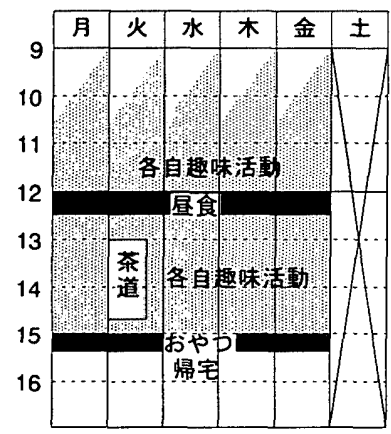

施設A
穆宅

※1）第1、3週のみ

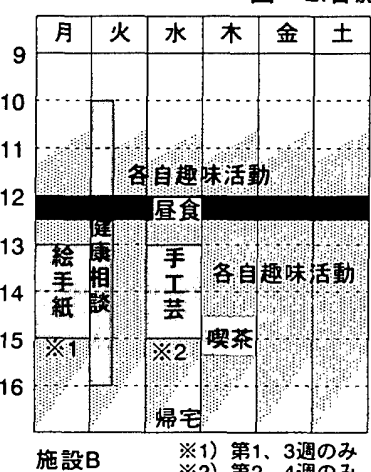

図・3.各施設の曜日別プログラム
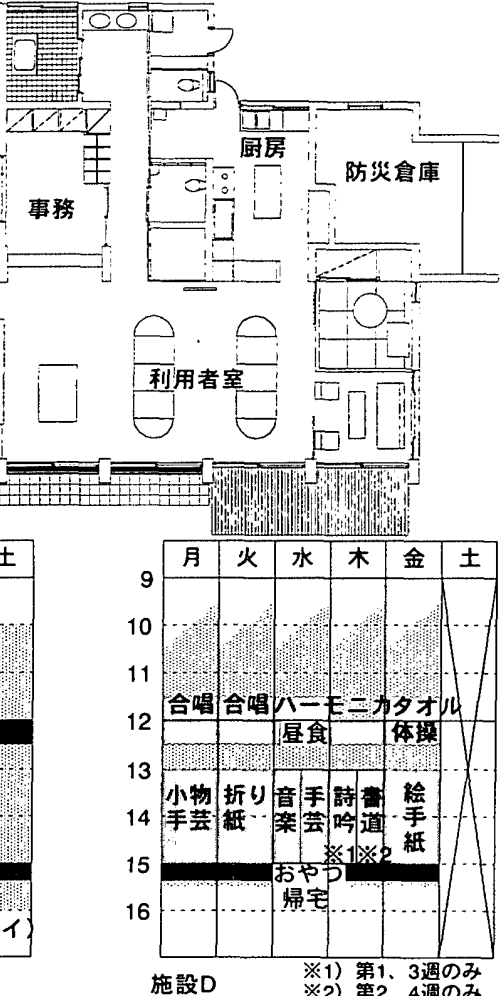

斜線は各プログラムに厳密な時間が決まっていないことを示す 
えるのではなく、全体的な状況の中での相対的行動として捉えるこ とにより、空間の使われ方の特性の把握を試みた。

\section{3)ミニデイの可能性と限界に関する考察（第6章）}

上記の結果をもとにミニデイの可能性と限界について論じる。

\section{3-2.調查の方法}

本研究の調查対象は、東京都M市で展開されるT事業に基づく4つ のミニデイ施設(ミニデイT.H.)である神4)。2002年4月から 2003 年 6 月まで、各施設における利用者の終日行動観察調查を断続的に行っ

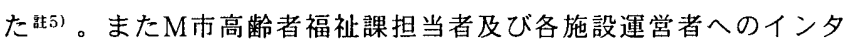
ビュー調查・資料収集を適宜行った。さらに2002年12月には各施設 の利用者の属性調查を行った。

\section{4. ミニデイT.H.の概要と施設型の分類 \\ 4-1.T事業の主旨時6)}

調査対象施設のミニデイT.H.は東京都M市等による補助金事業（T 事業）によって運営さ扎ている。従って介護保険報酬で運営される 一般型デイやミニデイとは異なる。介護保険の「公助」、自らの資 金でサービスを購入する「自助」に対して、地域の互助的な関係に よる「共助」システムの構築が事業の主旨である。

\section{4-2.ミニデイT.H.施設概要}

表・1に調査対象施設ミニデイT.H.の概要、図・2に平面図を示 す。T事業では地域の資源を有効活用することも一つの目的であり、

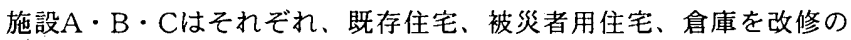
上、転用しており、施設Dのみ新築である。サービスに関しては4施 設ともミニデイサービスを基本としているが、施設Cのみ同時に ショートステイサービスも提供している。

運営団体は、施設 $\mathrm{A} ・ \mathrm{D}$ が地域住民グループ、施設 B・Cが地域介 護や障害者施設運営のNPO法人である。施設Aでは代表が現場全体 に気を配りサポートのスタッフが主に調理・配膳を担当している。 施設BはNPO法人の非常勤スタッフのよるローテーション制であ る。施設 Cでは主に訪問ケア主体のNPO法人のスタッフによるロー テーションが組まれている。そのため痴呆の程度が重い利用者の対 応も可能である。施設Dでは、運営担当のチーフスタップ調理ス タッフとプログラムを担うボランティアの分業によって運営されて いる。プログラムのボランティアは、運営者の知合いのピアノの先 生や元幼稚園の先生等18人が参加している。

図・3に各施設毎の矅日別プログラムを示す。施設Aでは火曜日の 午後以外に特にプログラムはなく、専ら各人が手工芸等をして過ご す。基本的には内容は自由だが、手を動かすことが一種のルールと いえる。施設 Bでは、月に4回のプログラムがある以外は、各人が好 きなことをして過ごす。第2・4水曜の手工芸は、あるボランティア 指導によるものである。施設Cでは痴呆の程度が重い利用者が多いの で、ほとんどプログラムはなく個別の対応である。施設Dでは日替わ りで何らかのプログラムが提供される。図・3では各施設の差異が表 れているが、プログラム提供の有無は、利用者の身体状況、運営方 針等によるものといえる。

図・4は各施設の開設後からの月別の一日当たりの平均利用者数の 推移を示す。施設 $\mathrm{A}$ ・ B・C・Dは、開設 1 年をすぎた頃から、それぞ れ8人、5人、3人、10人程度で安定してきていた。これらをもとに、 各施設の利用者室における平均人口密度 $\left(\mathrm{m}^{2} /\right.$ 人) を算出すると、そ

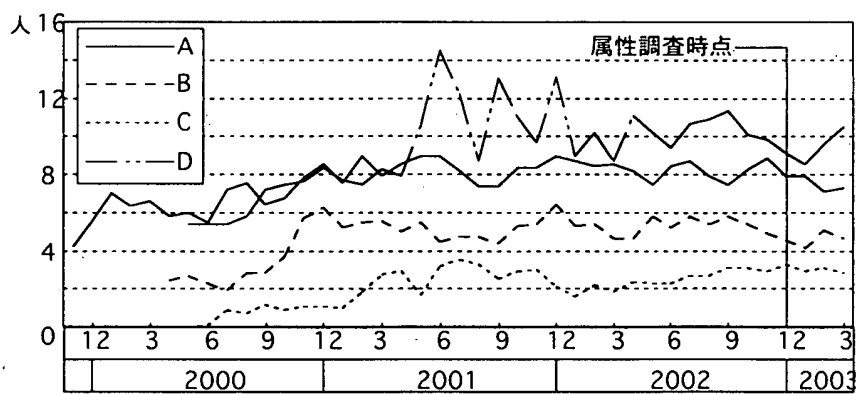

図・4.各施設の開設後の月別一日平均利用者数の推移 人
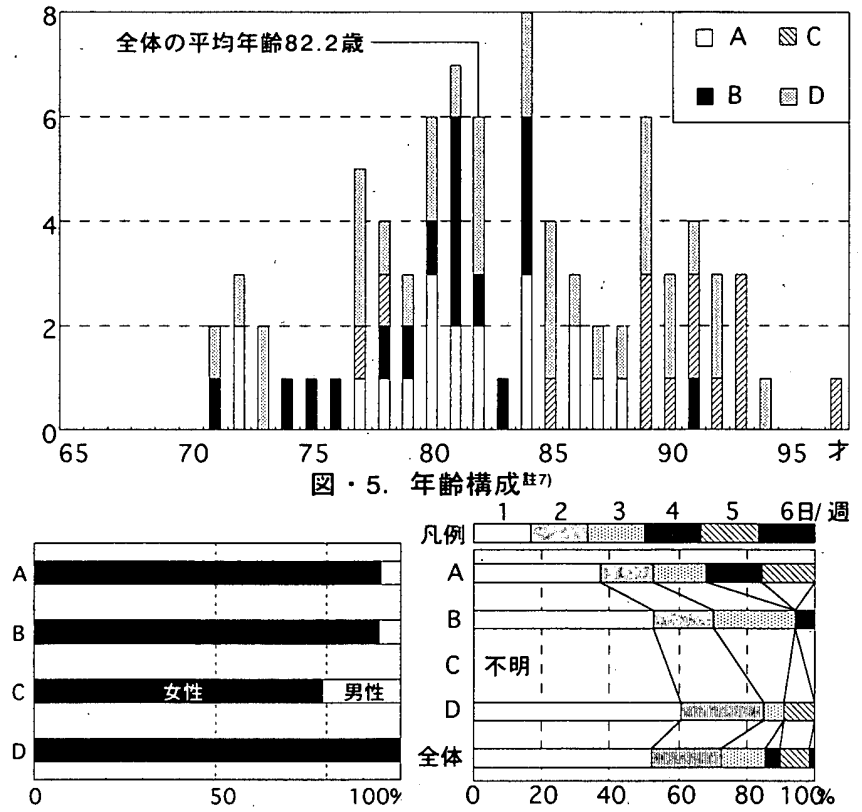

図・6.各施設の利用者男女比

图・7. 施設別の利用日数

表・3.各施設別の利用者のADL
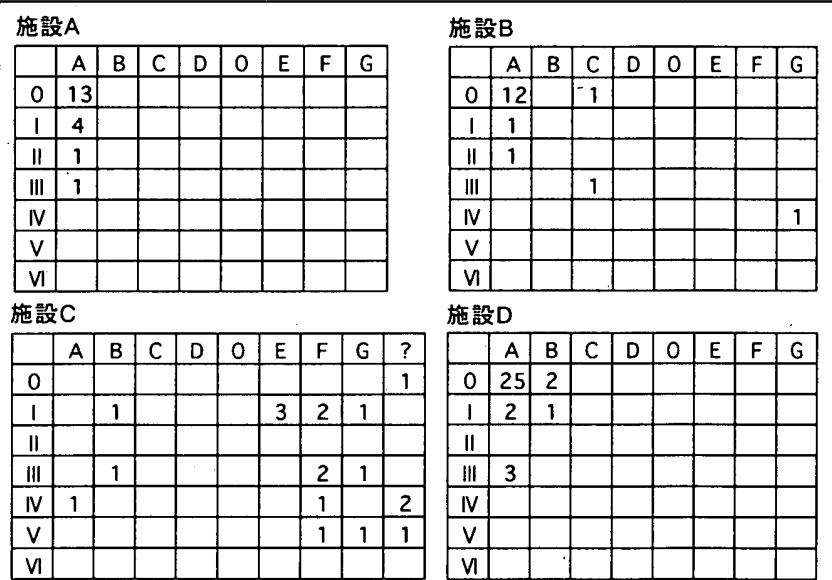

施設D

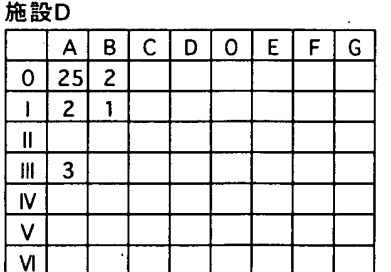

施設CではADLが不明の利用者は「?」とした

口ADL自立度のスケール (Katz,S.)

A ; 食事、排泄コントロール、移動、トイレ使用、更衣、入谷の自立

B ; 上記1项目以外は自立

； 入浴と他の1項目以外は自立

D ; 入浴と更衣と他の1項目以外は自立

; 入浴と更衣、トレの使用と他の1项目以外は自立

$F$; 入浴と更衣、トイレの使用、移動と他の1項目以外は自立

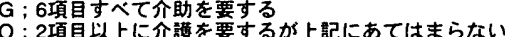

口痴呆スケール (BERGER)

0 : 癖なし

$1:$ 物忘れがあるが、日常瞢境てははとんど哩題なし

2: 既知の環境においては自立している

：既知の環境においては指音、助言を必要だが、指示のみで十分である

: 指示だけでは不十分で、具体的な介助を必要と劣る

:日常行為全てに介助が必要であり、言語による会話が成立しない

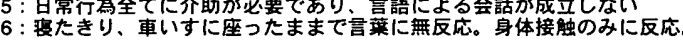




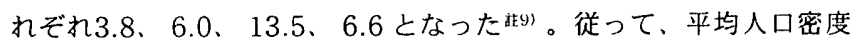
は $\mathrm{A}<\mathrm{B}<\mathrm{D}<\mathrm{C}$ とう関係にある。

\section{4-3.利用者属性}

図・6に各施設別の利用者の男女比を、図・5に4施設の利用者の年 齢構成を示す。利用者の男女比は、施設C以外、利用者はほぼ全員が 女性であった。各施設每の利用者の平均年齢は順に81.2歳,80.3歳 ,84.4歳,83.3歳であった。どの施設も 80 代前半の後期高齢者であ り、施設Cの平均年齢が若干高いが、特に大きな違いは見られなかっ た。表・3に各施設毎の利用者の $\mathrm{ADL}$ 、痴呆の程度を示す。表・3に より施設Cの利用者属性が他の施設と傾向が異なることがわかる。つ

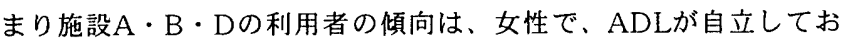
り、要介護度の認定もなく痴呆の程度も軽い。一方、施設Cの利用者 は、他施設に比べて、ADLが低く痴呆の程度も重い。従って、利用 者属性の点から、施設 $\mathrm{A} \cdot \mathrm{B} \cdot \mathrm{D}$ は比較的自立度の高い高齢者を対象 とし健康維持・寝たきりや要介護状態を予防する「予防型」、また 施設Cは痴呆性の高龄者を対象とする「痴呆特化型」と定義した。施 設 $\mathrm{A} \cdot \mathrm{B} \cdot \mathrm{D}$ 表・1に示す利用対象者の規定に沿ったものである。一 方、施設Cでは利用規定として特に制限を設けなかったため、当初は 利用者層に偏りはなかったが、徐々に痴呆性老人に偏っていった非10)。

図・8は各施設の利用者の居住形態の割合を示す。施設A、B、Dで は、独居高齢者が割を占めていた。これにより「予防型」のミニデ イT.H.が、独居高齢者にとって社会的な接触の場としての機能を果 たしていることがわかる。これらの施設が独居者を対象として規定 しているわけではないことを考慮すれば、結果として独居者の二ー ズが存在していることを示すものと捉えられる。また、家族と同居 しているが日中は独居となる者も各施設で2-3割程度おり、両者を併 せると各施設で6-7割は日中の独居者の利用であり、「予防型」の利 用者の傾向の特徴を示すものと思われる。

上記では各項目毎に利用者属性を見てきた。ここでは特に「予防 型」（施設 $\mathrm{A} ・ \mathrm{~B} \cdot \mathrm{D} ）$ の利用者69名を対象として、ADL・痴呆度・ 居住形態・現在の住まいの居住歴の組合せによる分類を試みた （表・4）。これらの組合せは理論的には396組可能であるが、少な くとも一人は存在した組合せは全部で19組であった到1)。うち $10 \%$ 以上の比率を占めるものは4組であった。それらは、いづれも自立し ており、痴呆がなく、現在の住まいに10年以上住んでいる高齢者で あり、単身や家族同居等の居住様態の違いによって4通りとなった。

これが大凡の「予防型」の利用者像といえる。

\section{4-4.利用傾向}

図・7は各施設每の利用者の利用日数の比率を示す。全体の 7 割の 利用者が週 $1 \sim 2$ 日利用していた。中には週5〜6日利用する人も見ら れミニデイT.H.が利用者の生活に深く根付いている様子も䚐える。

\section{4-5.利用圈域理12)}

図・10は各施設每の距離別利用者累積出現率を示す。施設 $\mathrm{A} ・ \mathrm{~B} \cdot$ Dは $50 \%$ 出現距離は約 $250 \mathrm{~m} \sim 400 \mathrm{~m} 、 80 \%$ 出現距離は約 $525 \mathrm{~m}$ $780 \mathrm{~m}$ であった。一方、施設Cの $50 \%$ 出現距離は約 $950 \mathrm{~m} 、 80 \%$ 出現 距離は約 $3,700 \mathrm{~m}$ であった。ここでも施設 $\mathrm{A} ・ \mathrm{~B} ・ \mathrm{D}$ はおおよそ似たよ うな傾向を示す一方、施設Cのみ利用圈域が大幅に広い。これは施設 Cの利用者は約 8 割が車で送迎されていることと関係が梁いと考えら れる（図・9）。同図によると施設A・B・Dの利用者の通所手段は少 なくとも 8 割以上が徒歩であった。また全体で見ても700m以内の利
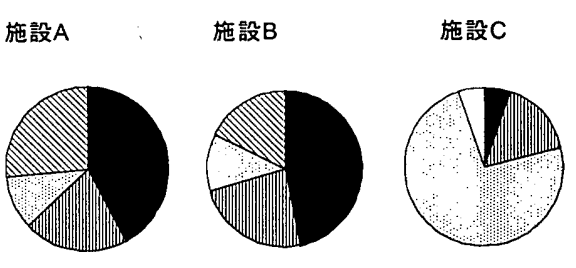

施設D

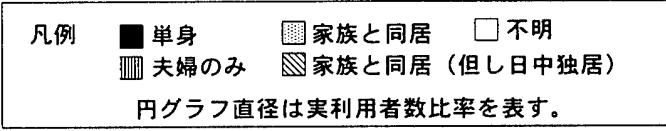

図・8.各施設の利用者の居住形態の割合

表・4.予防型のミニデイT.H.の利用者属性の分類

\begin{tabular}{|c|c|c|c|c|c|}
\hline No. & $\begin{array}{l}A \\
D \\
L\end{array}$ & 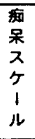 & $\begin{array}{l}\text { 居 } \\
\text { 住 } \\
\text { 形 } \\
\text { 笖 }\end{array}$ & 居 & $\begin{array}{l}\text { 入 } \\
\text { 数 } \\
\text { 毞 }\end{array}$ \\
\hline 1 & A & 0 & 1 & - & $27.5 \%$ \\
\hline 2 & $A$ & 0 & 4 & 1 & $15.9 \%$ \\
\hline 3 & $A$ & 0 & 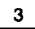 & & $14.5 \%$ \\
\hline 4 & A & O & 2 & 1 & $10.1 \%$ \\
\hline 5 & A & 1 & 1 & & $7.2 \%$ \\
\hline 6 & $A$ & 0 & 1 & & $2.9 \%$ \\
\hline 7 & A & 3 & 1 & 1 & $2.9 \%$ \\
\hline 8 & B & 0 & 3 & 1 & $2.9 \%$ \\
\hline 9 & A & 0 & 4 & & $1.4 \%$ \\
\hline 10 & A & 1 & 3 & 2 & $1.4 \%$ \\
\hline 11 & A & 1 & 4 & 2 & $1.4 \%$ \\
\hline 12 & A & 2 & 1 & 1 & $1.4 \%$ \\
\hline 13 & A & 2 & 4 & 1 & $1.4 \%$ \\
\hline 14 & $A$ & 3 & 3 & 1 & $1.4 \%$ \\
\hline 15 & A & 3 & 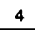 & 2 & $1.4 \%$ \\
\hline 16 & B & 1 & 3 & 2 & $1.4 \%$ \\
\hline 17 & C & 0 & 4 & 2 & $1.4 \%$ \\
\hline 18 & c & 3 & 3 & 2 & $1.4 \%$ \\
\hline 19 & $G$ & 4 & 2 & 1 & 1.4 \\
\hline
\end{tabular}
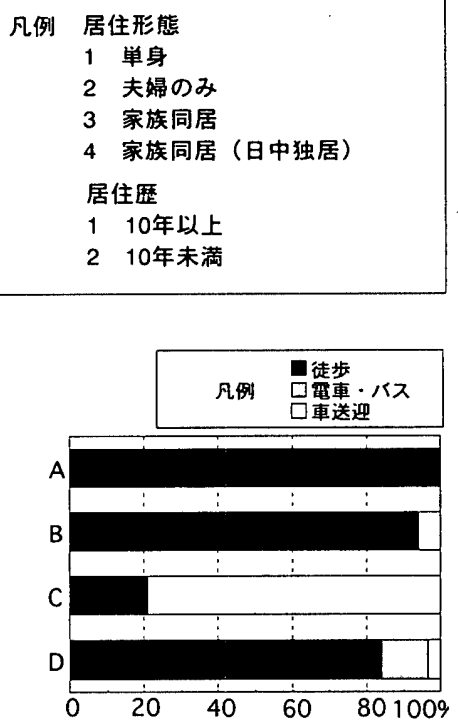

図・9.各施設の通所手段の割合

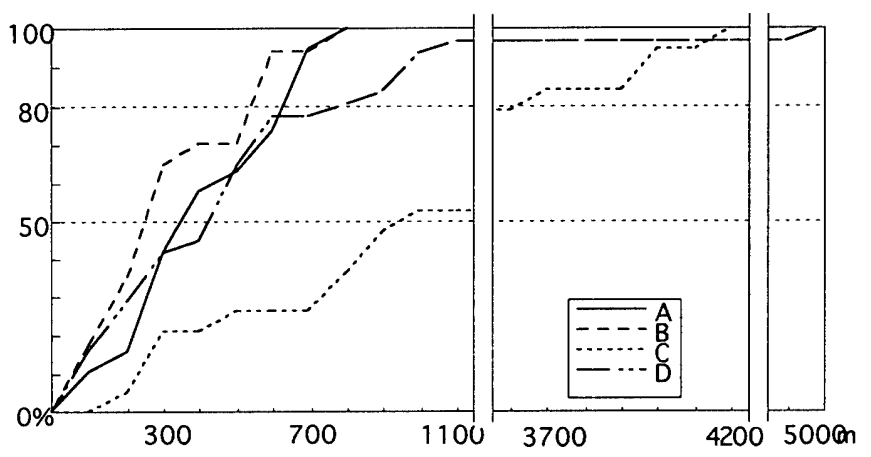

図・10. 各施設の距離別利用者累皘出現率

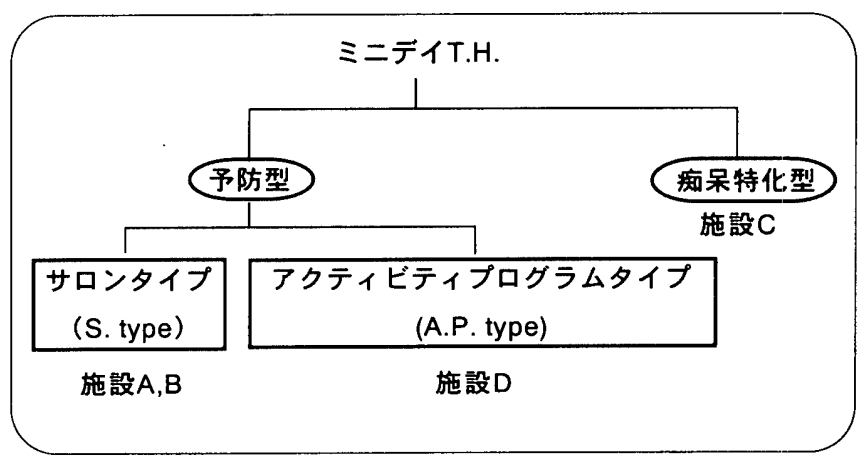

図・11. ミニデイT.H.の施設型の分類 
用者の通所手段は9割以上が徒歩であった。各施設は事業方針によっ ておおよそ1丁目を利用圈域として設定する予定であうたが、未だに 全市的に施設が整備されていないこともあって棐(3)、実際の利用圈域 はそれよりも広がっていた。また施設Cの利用圈域が突出して広い理 由として、痴呆性の高齢者を対象として、比較的フレキシブルな ニーズに応える施設が他に見あたらないことも挙げられる。

\section{4-6.ミニデイT.H.の施設型の分類}

以上よりミニデイT.H.4施設を下記のように分類した（図'11）。 まず利用者属性によって、施設A、B、Dの利用者は、要介護度認定 のない自立した高齢者がぼとんどで、健康維持・寝たきりや要介護 状態を予防する「予防型」と分類した。一方、施設Cは痴呆性高齢者 を対象とする「痴呆特化型」と分類した。また、同じ「予防型」で も、4-2で見たとおり、施設側の提供するプログラム活動の有無に よって、さらに「サロンタイプ (S.type)」と「アクティビティプ ログラムタイプ（AC.PR.type）」の 2 つに細分類した。

\section{5. 各施設における空間の使われ方の特性}

本章では各施設における空間の使われ方の特性を明らかにする。 5-0.分析の方法

本章の分析では、空間の使われ方の特性を見るにあたり、各利用
者の活動の集積によって構成される全体的状況の観点からの分類を 試みた非14)。なぜならば、これまでデイの空間内での行動は個人単位 の考察が行われてきたが、通所施設の一つの大きな役割が「社会的 な接触の場」にあるならば、各施設の全体的状況の中で、各個人が 他者との関係を測りつつ、いかなる行為をとりうるかが重要である と考えるからである。これは「すべての集まりはある程度それにふ

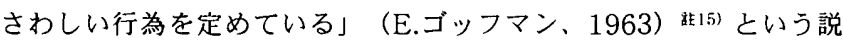
に基づいている。特にミニデイは全体状況の点において各施設の特 徵が顕著に表れるものと思われる。

具体的には、まず観察調查で得られた各施設における10分間隔の 終日活動マップを、各施設毎に 2 日分ずつ抽出した。この際「サロ ンタイプ」の施設に関しては、プログラム活動が全くなかった日 と、プログラム活動があった日辣16) を選んだ。また「アクティビティ プログラムタイプ」の施設については、プログラムがーつのみの日 と二つのプログラムが同時進行した日を選んだ。次に、それぞれの 活動マップから、二人以上の利用者がいる場面を抽出した。そし て、それらの場面に対して、A.その時間帯が施設の公式なプログラ 厶時間帯 $(\mathrm{O} ;$ Official) か否か $(\mathrm{N} ; \mathrm{No}-\mathrm{Official}) 、 \mathrm{~B}$.その時の利用者の 活動の種類数 (活動軸;S(Single),M2(Mixture of 2activities),M3 (Mixture of over3activities),M-Ind(Mixture of Individual

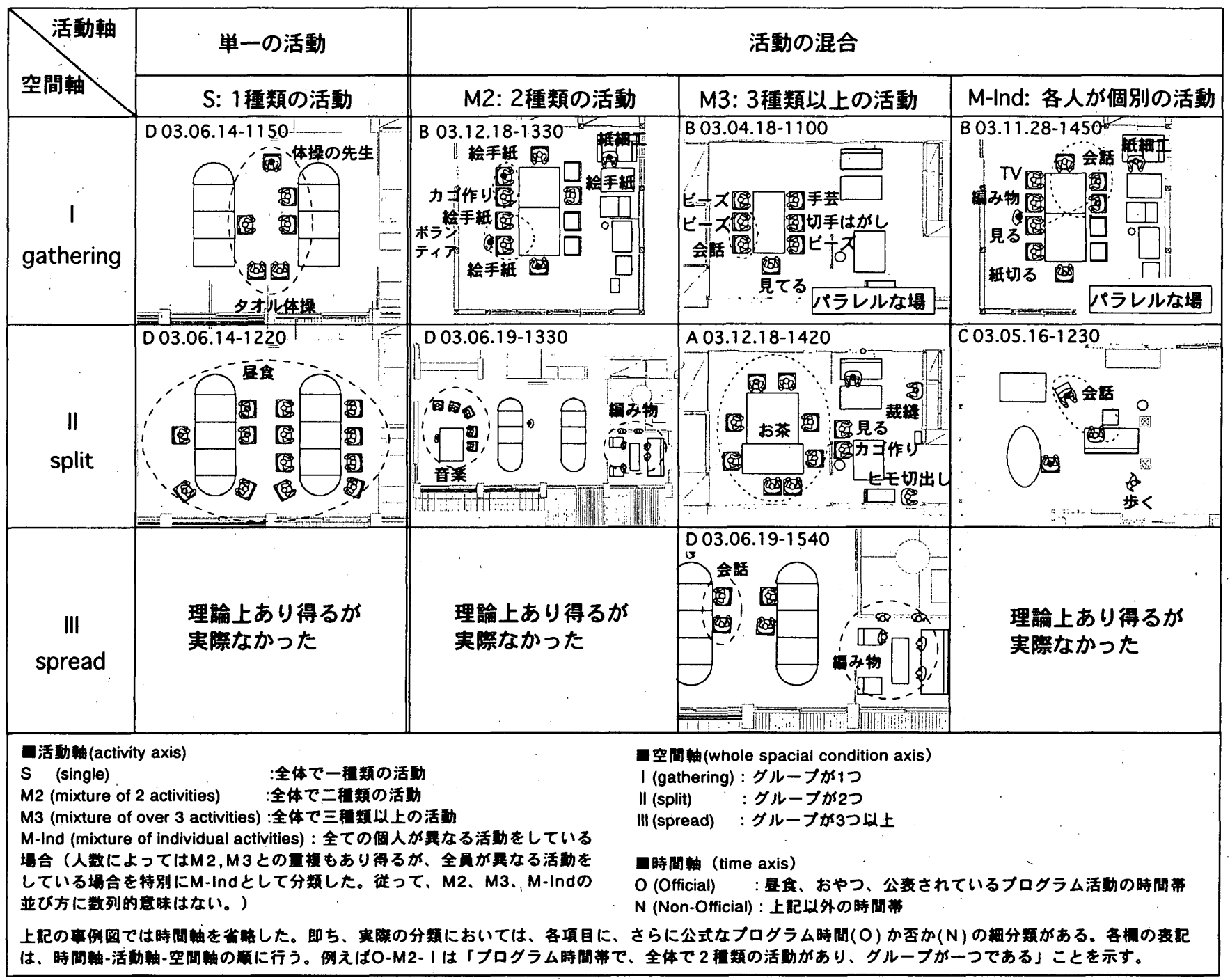

図・12.分類の重例图 
activities)、但しスタッフの活動は含まない) 竦17)、C.その時のグ ループ数（空間軸; I (gathering)、II (split)、 III (spread)) によって 分類した。この際、公式なプログラム時間とは、昼食、おやつ、公 表されているプログラム活動をさす。またグループ数は、主に一つ のテーブルを囲むグループを 1 とカウントし、同じ空間内にそのよ うなグループがいくつ同時に存在するかを数えた。これらの分類軸 を導入することによって、施設内における全体的状況を客観的に分 類することができると考えた。図・12に各項目の事例を示す。ま た、今回は調查対象ではないが、一般型デイについてもこれらの軸 を用いてミニデイと対比的に示しうると考えた。尚、行動観察調查 時期はいずれの施設も開設後 2 年目に当たるため、その状態は、初期 の事業計画に対してある程度安定したものと言える。各施設每に分 類の結果をまとめたものが図・13〜図・20である贸18)。30\%以上の 出現率であった欄に濃い網掛けを施した。

\section{5-1.予防型ーサロンタイプ(S.type)}

S.typeはほとんどプログラム活動のない日であることから、プロ グラムなしの日のデータが通常のものとして受け取れる。施設Aの場 合、図13.N-M3-I 、即ち一つのテーブルを囲んで各人がやりたいこ とをしている状態が典型的な場面である。一方、施設 Bの場合、同 様に一つのテーブルを囲んで各人がやりたいことをする場面が多い が、さらに各人が完全にバラバラな活動をする図15.N-M-Ind- I が 典型的場面として抽出された。これらのような「同じ場を共有しつ つ別々の活動をする状態」を「パラレルな場」と呼ぶことにする部199。 この現象の生起要因としては、第 4 章で見たプログラムの差異や利 用者属性等の社会的・人的環境も含めた総合的な環境による部分も あるが、小規模な空間に依る部分も大きいと思われる。つまり、あ る程度、空間的に限定された方が、例え異なる活動を行っていて も、同じ場を共有している一体感が増すものと思われる。また同じ S.typeでもこのような差異がある理由として次のものが考えられ る。一つはこれらの施設間で平均的な利用人数が異なり、人数が多 ければ多いほど活動が重複する可能性が高くなるため、もう一つは 施設Aでは何らかの手芸をすることが奖励されているため、各利用者 間で互いに教えあう等して同じ活動が伝播するためであろう。

またS.typeにおいて、月に数回のプログラムがある日のデータを 示すのが図・14、図・16である。施設A、Bともに活動軸と空間軸の 双方においてプログラムのない日の傾向との類似性が見られる。こ れは主にプログラムのある日でも、プログラムのない時間帯は通常 の状態であるためと考えられる。但し、空間軸をよく見ると、施設 $\mathrm{A}$ の場合、プログラムのある時間帯には、プログラムに参加するグ ループと他の活動をするグループで空間的に分かれる場面が見られ た（図14.O-M3-II、図14.O-M3-III）。一方、施設Bでは、異なる 活動をする人も、同じテーブルに同席している場面が見られ（図 16.O-M2-I，図16.O-M3-I）、空間軸 II、II への展開がなかっ た。即ち、空間的には未分化であった。これらの差異の要因は、 テーブルが複数個あるか否かという空間的余裕と設えの差異による ものと考えられる。空間的余裕のない施設Bにおいては、通常のプロ グラム活動のない時からして異なる活動が同じ場において混合する ことが標準化している（パラレルな場）。そのため、プログラム活 動時においても、その状態の影響を受けているものと思われる。即 ち、ここでは空間によって活動を分けるのではない形が見られた。
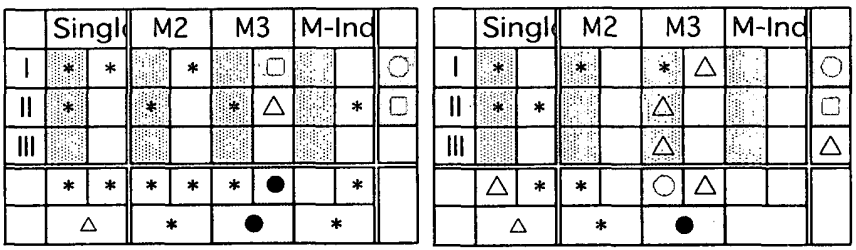

図・13.施設A-NPR(2003.04.18)

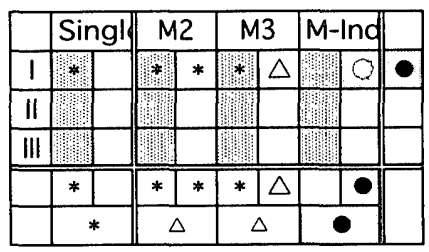

図・14.施設A-1PR(2003.12.10)

図・15.施設B-NPR(2003.11.28)
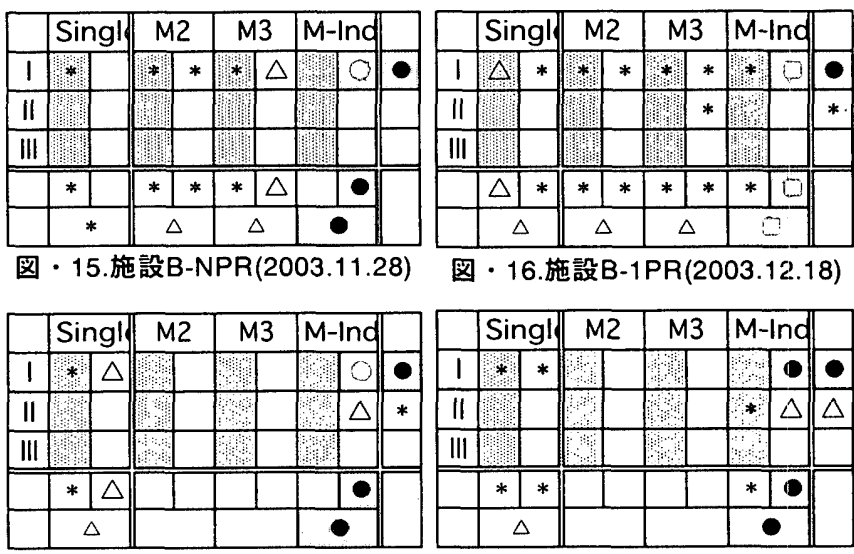

・16.施設B-1PR(2003.12.18)

図・17.施設C-NPR(2003.05.16)
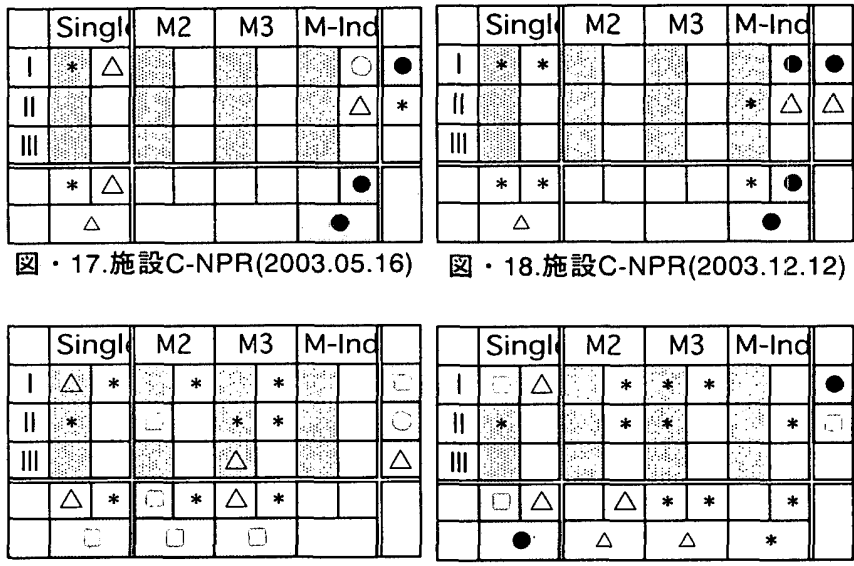

図・18.施設C-NPR(2003.12.12)

図・19.施設D-2PR(2003.06.19)

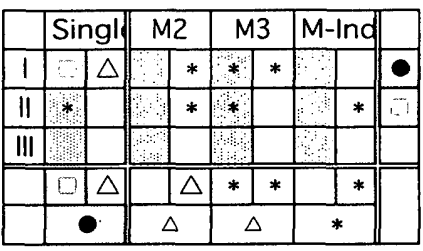

\begin{tabular}{|c|c|c|}
\hline 凡例 & 0-15\%末満 & O $45.60 \%$ 末満 \\
\hline い網掛けは & $\begin{array}{ll}\triangle & 15-30 \% \text { 末満 } \\
\square \quad 30-45 \% \text { 末渾 }\end{array}$ & $60-100 \%$ \\
\hline
\end{tabular}
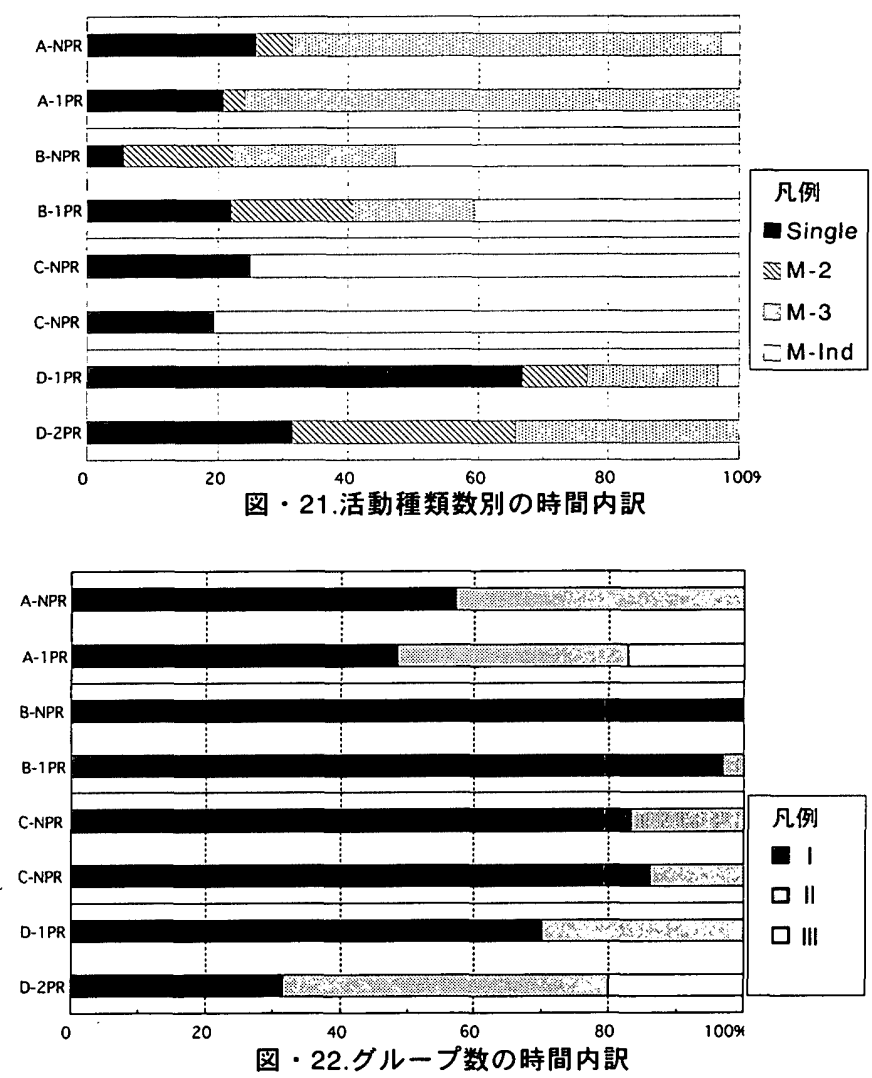


\section{5-2.予防型ーアクティビティプログラムタイプ(AC.PR.type)}

AC.PR.typeでは毎日何かしらのプログラム活動があるので、プロ グラム活動が一つの場合と二つの場合を比較した。プログラム活動 が一つの日の場合、図19.O-S-I が最もよく出現している。一方、 プログラム活動が二つの日では、図20.O-M2-II が多く見られ、さら に図21.O-M3-IIIにも展開している。即ち、プログラムグループ毎の 空間的分離が顕著に見られた。この要因としては空間的展開の余裕 があることが挙げられる。

\section{5-3.痴呆特化型}

参考までに、痴呆特化型の施設Cについても述べる。施設Cでは、 調查時の利用者数が 2 人であったため、その利用者間での関わりが ない限り、ほとんど全ての時間帯がM-Indに分類された。即ち、隣 に座りつつもほほ個人ベースの活動をする場面が顕著に見られた。 これらの結果は、施設Cの利用者数が一日平均 2 ～3人であること、ま た利用者のADLが低く、痴呆の程度が比較的重いため、個人的なケ アを受ける場合が多く、具体的な活動が難しいことから、ある程 度、妥当なものと思われる。

\section{5-4.各施設型の特性の比較}

次に、第4章で分類した施設型と本章で分類した特性の傾向を比較 する。第4章では利用者属性やプログラムの有無などの客観的情報を もとに分類した。一方、本章では実際の行動場面から、全体状況を 活動種類とグループ数によって分類した。その両方の方法によっ て、各施設が同様に分類されたことは、利用者属性・プログラムの 有無等と、各空間の使われ方に相関があることを示すものとして特 筆すべきことと思われる。

次にAC.PR.typeとS.typeを比較すると、活動軸において顕著に差 異が見られた。AC.PR.typeの場合、Single側に笴っている。これ は、AC.PR.typeの場合、そのプログラムに利用者がほほ全員が参加 するため、活動数が一つにまとまっていることを示す。一方S.type の場合、Mixture側に寄っている。これは、前述の通り、各人がそれ ぞれの活動をしている集積が全体状況を作っていることを示す。こ のように各施設型において全体の活動の様態が異なるものといえる。

また各施設において、30\%以上の出現率があった項目をピック アップしてーつにまとめたのが図・23である。S.typeの特幑として， 「一つの場を共有しつつ、別々の活動をする（パラレルな場）」、 一方、AC.PR.typeは「一つの活動を共有し、活動毎に場所を分け隔 てる」という特性が指摘される。つまり、S.typeは「場が結ぶ」、 一方、AC.PR.typeは「コトが結ぶ」ものと対比されよう。また空間 的余裕がない場合（SALON-B）には「場所は変わらずに時間によっ てモードがかわる」、空間的余裕がある場合(SALON-A,AC.PR) に は「場所を変えてモードを変える」特性も指摘できる(図・24)。

また、あえて一般型デととの対比を行うため、一般型テイの典型 的と推測される状況を、筆者の経験的判断により些20)、図・23にれ 印で示した。即ち、S-I（例：全体体操等）、S-III.(例：テーブル に別れて食事等）、M3-III（例：各テーブル毎に趣味活動等）であ る。一般型デイの傾向はAC.PR.typeに近いものと思われる。こうし て一般型デイと比較すると、サロンタイプのミニデイT.H.固有の空 間の使われ方の特性として「パラレルな場」が指摘される。これは 場所としては小さくしかも単純であるにもかかわらず、その中で多 様な活動が見られる点で、一般型デイのような多様な活動を内包す

\begin{tabular}{|c|c|c|c|c|c|c|c|}
\hline & Single & $M 2$ & \multicolumn{2}{|c|}{ M3 } & \multicolumn{2}{|c|}{$M-\operatorname{lnd}$} & \multirow[b]{2}{*}{$\mathrm{Sa}, \mathrm{Sb}, \mathrm{D}, \mathrm{AP}$} \\
\hline 1 & $A P \cap$ & ए' & . & $\mathrm{Sa}$ & 19y & $S b, D$ & \\
\hline 11 & प' & AP & (1) & & पy & & $\mathrm{Sa}, \mathrm{AP}$ \\
\hline III & त) & W"y & $x$ & & & & \\
\hline & $\mathrm{AP}$ & $\mathrm{AP}$ & Sa & $\mathrm{Sa}$ & & $\mathrm{Sb}, \mathrm{D}$ & \\
\hline & \multirow[t]{2}{*}{ AP } & $\mathrm{AP}$ & \multicolumn{2}{|c|}{$\mathrm{Sa}, \mathrm{AP}$} & \multicolumn{2}{|c|}{$\mathrm{Sb}, \mathrm{D}$} & \\
\hline & & 略記号 & $\begin{array}{l}\text { Sa } \\
\text { Sb } \\
D \\
\text { AP }\end{array}$ & $\begin{array}{l}\cdot-\mathrm{Sa} \\
\cdot \mathrm{Sa} \\
\cdot \mathrm{D} \\
\cdot \mathrm{AC}\end{array}$ & $\begin{array}{l}\text { on type } \\
\text { on type } \\
\text { mentia } \\
\text { ivity } P r\end{array}$ & $\begin{array}{c}\text { (施設A } \\
\text { (施設 } \\
\text { (施設 } \\
\text { ogram }\end{array}$ & ype (施設D) \\
\hline
\end{tabular}

図・23.施設型毎によく見られた様態の傾向

\begin{tabular}{|c|c|c|c|}
\hline & SALON-A & SALON-B & AC.PR (D) \\
\hline 活動 & $\begin{array}{c}\text { 各々が別々の } \\
\text { 活動をする }\end{array}$ & $\begin{array}{c}\text { 各々が別々の } \\
\text { 活動をする }\end{array}$ & $\begin{array}{c}\text { 各々が同じ } \\
\text { 活動をする }\end{array}$ \\
\hline 共有するもの & 場所 & 場所 & 活動 \\
\hline モード变更 & 場所を变える※ & $\begin{array}{c}\text { 席が变わらず } \\
\text { 時間帯による }\end{array}$ & 場所を变える \\
\hline
\end{tabular}

※週に一度のプログラム活動（お茶）の時のみ見られる 図・24.各施設型の特性

る大きな空間とは異なる。またいわゆる多様な活動を包含する多様 な場を推奖する計画論踏11 とも異なる立場にある。

\section{6. ミニテイの可能性と限界に関する試論}

本稿は東京都M市等による補助金事業によって運営されているミ ニデイT.H.を対象としたケーススタディであるため、ミニデイ一般 に昖大して解积することは必ずしも適切ではないかもしれない。し かしながら、ここで見られた結果をもとに、あえて試論としてミニ デイの可能性と限界について述べたい。

まずミニデイの可能性について。予防型の施設に対して、第4章の ような利用実態が見られたことは、少なからずこれらの場を求めて いるニーズがあることを示すものと考えられる。つまり、通所施設 は要介護者に介護サービスを与えるだけの場ではなく、要介護の有 無を問わず、特に独居、日中独居の高齢者の社会的ニーズがあるも のと言える。

またS.typeのように、アクティビティプログラムの有無にかかわ らず、施設利用の定着が見られることから、利用者にとっての居場 所としての役割といった、より本質的な意味づけもあると考えられ る。その際に、第5章で定義した「パラレルな場」は、ミニデイT.H. 固有の状態であり、一人一人が個別的な活動しながらも、全体的な 共有感を得られることは、個々の居場所を保証しつつ、通所施設の 本質的意義である「社会的な接触の場」としても機能する重要なあ り方の一つであるといえる。

次に、ミニデイの限界について述べる。ミニデイT.H.の施設型を 分類する際に利用者属性を基準にしたが、これは小規模な集団にお ける精神的レベルの差の大きな利用者どうしの混合処遇が難しいと 考えられることによる。実際、これらのミニデイT.H.は、アクティ ビティプログラムや場を共有手段としていると指摘したが、そのた め、それらの秩序を共有できない利用者の利用は難しい。註 10）の 事例のように、利用者層の偏りは、施設による利用者層の設定とい 
う誘導的側面と同時に、利用者間の自然な志向が反映されたもの と考えられる。従って、自律的な集団形成の観点から、ミニデイ T.H.で見られた予防型と痴呆特化型の 2 つがミニデイの基本的 な施設型であるといえる。即ち利用者の精神的な属性が施設種の 分水嶺になるものと考えられる。何らかの身体的障害があっても 精神的に自立していればミニデイT.H.の利用は可能である事例 も見られた。ミニデイT.H.が二つの型に分離しているのは、一 般型テイにおいては混在している利用者属性が、小規模であるた めにどちらかに特化せざるをえない結果であろう。

しかしミニデイが必ずしも理想的であるとは限らない。なぜな らば、ミニデイT.H.においても、年々、利用者の虚弱化が問題 として顕在化しつつあるからである。本格的なケアスタッフのい ない状態では対応が難しいのである。利用者とスタッフ、或いは 利用者間の継続的関係構築の観点からすれば、何らかの身体的ケ アの必要性が生じた後にも、自律的な集団を形成しうる限り継続 利用可能なシステムが模索されるべきである。しかしながら、前 述のように規模が小さいだけにその混合処遇が難しいというジレ ンマが存在する。

\section{7. まとめ}

本稿では、まず一般型デイに対する実験的施設としてのミニデ イT.H.について、利用者属性傾向から「予防型」と「疾呆特化 型」の2つの施設型に分類した。ミニデイではその小規模故に、 利用者の精神的属性が施設種の分水嶺になることから、この二つ が基本的な施設型であることを指摘した。さらにプログラムの有 無により、「予防型」を「サロンタイプ」と「アクティビィティ プログラムタイプ」に細分類した。そして次に各施設における空 間の使われ方の特性を指摘した。特に「サロンタイプ」のミニデ イT.H.に固有の空間の使われ方として「パラレルな場」が挙げ られた。これは一般型デにおいて典型的なワンルーム型の比較 的大きな空間内での様態とは異なるものである。この特性は通所 施設の意義である「社会的な接触の場」に対して、一つのあり方 を示しているものと思われる。この点等においてミニテイの通所 施設としての可能性を指摘しうるものの、同時に利用者の継続的 利用の観点からの限界もあることを指摘した。

\section{8. 今後の課題}

「痴呆特化型」のミニテイに関しては、今回、詳察できなかっ た。今後ニーズが增加する施設であると思われるが、そのあり方 に関する考察は今後の課題となった。加えて、以下の点を今後の 課題としたい。

・施設の空間規模の大小が利用者のコミュニケーション行為に与 える影響はいかなるものか？

・既存家屋を施設に転用することの環境行動的な意義は何か？

1）文献1）参照。

2) 例えば、文献2)等。

3）この図はM市高齢者福祉課資料(2002)をもとに作成した。

4）平成15年4月に5件目のミニデイが開所したが本稿では対象外である。 5)各施設への訪問調查日は以下の通り。

【施設A】 [2002]4/18、11/14、12/10、12/11 [2003] 4/15、4/18

(施設B】 $[2002] 5 / 14 、 5 / 24,9 / 5 、 10 / 17 、 10 / 24 、 10 / 31 、 11 / 28$ 、
$12 / 18,12 / 26,[2003] 2 / 6,2 / 13,2 / 20,3 / 6,3 / 13,3 / 20,3 / 27,4 / 7$, $4 / 10,4 / 17,4 / 24,5 / 1,5 / 15,5 / 29,6 / 5,7 / 3$

【施設C】 $[2002] 5 / 16 、 12 / 12$

[施設D] $[2002] 4 / 3 、 4 / 16 、 5 / 14 、 5 / 19 、 5 / 27$

6）下事業の蔇要を文献3）より引用する。

○事業は「公助・自助・共助」のバランスの取れた役割分担による地域福祉の 推進を進める上で、長い歷史と層の厚いボランティアなど、・.地域福祉に対 する市民の自主的な提案（共助）に対して、行政が場所と財源について支嗳を行 うしくみです。

私たちは、地域に生き、地域社会の中で多くの人たちと共に支え合って生きて います。高龄者や障害者が住み惯れた地域で、障害をもったとしてもその人の個

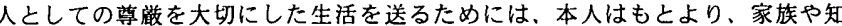
人、ボランティア、NPO等による支えあいのしくみが必要です。

一本人の自立・自尊の精神を大切にしながら、その人にあった多様なサービスを

柔軟・軽快に提供するために「近・小・軽の家」T事業を実施します。 5 つの挑戦

1.住民ニースに応じた柔軟・軽快なサービスの提供

2.民間の力の活用（作る福祉から使う福祉へ）

3.介護保險の限界を乗り越える

4.利用者が当事者としての役割を担って参加できる福祉へ

(自尊の尊重)

5地域に活力を生み出しサラリーマンが地域に参加する場を創出 7）施設Cでは50代の痴呆性の3名を受け入れていたがこの図では省略した。 8)施設Bの利用者属性表中、「G-N」の利用者は夫の付添いで利用していた が、属性調查後に利用中止し、一般型デイの利用日数を增やした。

9）各施設の利用者室とは、施設内において利用者が利用する部分を示す。具体 的には、事務室、玄閣、廊下、トイレ、㴻房、風呂、倉庫、別室等の面箖を除い たもの。

10）施設Cでは、開所当初には、比較的自立した利用者が見られたが、徐々に疾 呆性高踰者の利用者の增加と反比例するかのことく、利用が隇少していった。そ のことが利用者層が撚呆性高踰者に偏っていく傾向に拍車をかけ、相互作用的に 施設の性格が定まっていった。

また、これは痴呆性老人の受入れ先を求める潜在的ニーズが発現したことを示 す。例えば、デイとの併用利用者が数名おり、デイ利用日以外をミニゴイを利用 する、或いはデ利用時間終了後、家族帰宅時刻までをミニテイで過ごす等、デ イの補完的利用も見られた。

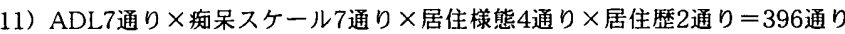

12）この項の分析方法、図表表現は、文献2）を参照にした。

13）ミニデイは、事業方針では既存のデイサービスセンターを合わせて I 丁目 にI 施設を整備目標としているが、未だ全市区域内に整備されていないため施設 分布に偏りがある。

14）尚、ここでいう「全体」とは、利用者スペースのうち、視覚的に一臨でき る䇩囲をさす。

15）文献4）参照。

16）「サロンタイプ」は、定義上、アクティビティプログラムがないのである が、月に数回程度、プログラムが開催される日がある。

17）アクティビティの分類において、例えば「編み物をしながら会話する」等 の重複行為は、なるべく物理的活動の方を抽出するようにした。これは、今回は 活動と空間の使われ方に焦点を当てた考察であるからである。

18）本章の分析軸表記に際し、文献5）を参考にした。

19）文献6）参照

20）筆者は、ミニデイと一般型デイの比較考察を行うため、同時期に同市内の 一般型テイ2箇所（それぞれ定員40名、35名）における行動観祭調查を行った。 詳細は別稿にて報告予定である。その結果をもとに一般型デイの典型的状況を判 断した。

21）例えば、文献2）等。

\section{参考文献}

1）大原一興：高龄者の生活拋点移動に関する建筑計画的研究、東京大学学位請 求論文、 1989 .

2）田中裕基、登張絵夢、上野淳、竹宮健司：自立高路者の地域生活支援施設 のあり方に関する研究、日本建築学会計画系論文集第562号.P.165-172. 2002.12.

3） T事業パンフレット、M市、2000.

4）E.コッフマン：集まりの構造、誠信書房、1963.

5）伊藤俊介： デンマークのフォルケスコーレにおける学習活動と空間の使われ 方について、日本建築学会計画系論文集第549号.P.145-152、2001.11.

6）山根寛ほか、集団と場、三輪書店、2000

本研究はユニオン造形文化財団平成14年度調查研究助成を受けた。

射辞

調査にこ協力いただきましたM市および各施設の利用者や運営者の方々にこの場 を借りて御礼申し上げます。

（2004年 1 月 10 日原稿受理，2004年 4 月16日採用決定） 